\title{
Respon Fisiologis Sapi Perah Dara Fries Holland yang Diberi Konsentrat dengan Tingkat Energi Berbeda
}

\author{
Physiological Response of Fries Holland Dairy Heifers \\ Fed Concentrate with Various Levels of Energy \\ Dadang Suherman ${ }^{1}$ dan B.P. Purwanto ${ }^{2}$ \\ ${ }^{1}$ Jurusan Peternakan, Fakultas Pertanian Universitas Bengkulu. \\ Jalan Raya WR. Supratman Kandang Limun Bengkulu 38371, Hp. 082126882867 Email: \\ dadangsuherman707@yahoo.com \\ 2 Departemen Ilmu Produksi dan Teknologi Peternakan, Fakultas Peternakan, \\ Institut Pertanian Bogor.
}

\begin{abstract}
The objective of the research was to study effects of feed energy of concentrate relationship with environment on physiological response of dairy heifers. The study used four dairy heifers with four treatments of concentrate energy in latin square design $4 \times 4$. The treatments of total digestible energy (TDN) were : P1 (TDN 60\%), P2 (TDN 65\%), P3 (TDN 70\%), and P4 (TDN 75\%) with crude protein (CP) 12-15\%. The research was carried out for 4 periods consisting of 21 days each period. Variables observed were environment factors such as air temperature, air humidity, THI, wind speed, and solar radiation; physiological response, TDN intake and growth of dairy heifers. Data were analized by variance and regression analysis followed by the LSD for any significant difference among treatments. Results showed that TDN intake for P1, P2, P3, P4 were 3.7, 3.8, 3.7 and $3.7 \mathrm{~kg}$, resvectively. The treatment was no difference on growth of dairy heifers $(\mathrm{P}>0.05)$. There was a variation on environmental factors on any periods. The treatments were significant on physiologis response $(\mathrm{P}<0.01) ; \mathrm{P} 4$ gave effect of more heat stress than else. Based on the result could be concluded that using feed energy TDN 65$70 \%$ gave optimum growth of dairy heifers without experience severe heat stress. Combination environment and high feed energy increased heat load to dairy heifers.
\end{abstract}

Keywords : feed energy, physiologis response, heat stress, dairy heifers

\begin{abstract}
ABSTRAK
Tujuan penelitian untuk mengetahui pengaruh tingkat energi pakan konsentrat yang berbeda dengan respon fisiologis sapi perah dara. Penelitian menggunakan empat ekor sapi perah dara dan empat perlakuan energi pakan konsentrat dengan Rancangan Bujur Sangkar Latin 4 x 4. Energi pakan konsntrat perlakuan, meliputi P1 (TDN 60\%), P2 (TDN 65\%), P3 (TDN 70\%), dan P4 (TDN 75\%) serta CP 12-15\%. Penelitian dilaksanakan selama empat periode serta setiap periode selama 21 hari. Parameter unsur lingkungan mikro terdiri dari suhu udara, kelembaban udara, THI, kecepatan angin, dan radiasi matahari, serta respon fisiologis, konsumsi TDN dan pertambahan bobot badan sapi perah dara. Data dianalisis menggunakan sidik ragam dan dilanjutkan uji beda nyata terkecil (BNT)). Hasil penelitian menunjukkan bahwa konsumsi TDN untuk P1, P2, P3, dan P4 masing-masing 3.7, 3.8, 3.7, dan 3.7. PBB sapi perah dara tidak berbeda nyata $(\mathrm{P}>0.05)$ pada setiap faktor lingkungan dan periode. Hasil penelitian pada respon fisiologis menunjukkan berbeda nyata $(\mathrm{P}<0.01)$, yang ditunjukkan P4 memberikan efek lebih rendah terhadap stress panas. Pemberian perlakuan energi pakan konsentrat $65-70 \%$ menunjukkan pertumbuhan optimum pada sapi perah dara. Kombinasi lingkungan dan pemberian energi pakan konsentrat yang lebih tinggi dapat meningkatkan pembebasan panas pada sapi perah dara.
\end{abstract}

Kata kunci : energi ransum, respon fisiologis, stress panas, sapi perah dara

PENDAHULUAN

Salah satu faktor yang sangat penting supaya ternak sapi perah dapat berproduksi optimum sesuai kemampuan genetiknya di daerah tropis, yaitu daya tahan ternak tersebut terhadap panas. Ternak sapi perah yang tahan terhadap 
panas dapat mempertahankan suhu tubuhnya dalam kisaran yang normal tanpa mengalami perubahan status fisiologis dan produktivitas (Tyler dan Ensminger, 2006). Dilain pihak, ternak sapi perah yang tidak tahan terhadap panas, produktivitasnya akan turun akibat menurunnya konsumsi pakan.

Hasil penelitian mengenai sifat daya tahan panas telah banyak dikemukakan terhadap ternak berdasarkan pada sumber panas dari luar tubuh, akan tetapi sumber panas dari dalam tubuh seperti pakan belum banyak dilakukan. Sejak lama diketahui bahwa pakan yang dikonsumsi berpengaruh meningkatkan laju produksi panas dalam tubuh atau biasa juga disebut efek kalorigenik pakan. Bagi mempertahankan kondisi homeostasis, ternak memerlukan energi dalam jumlah yang cukup. Energi yang dibutuhkan ternak dapat dicukupi dari pakan. Dengan demikian, makanan yang masuk ke tubuh ternak harus dicerna terlebih dahulu, untuk dapat memanfaatkan energi yang terkandung di dalamnya.

Ternak akan memproduksi panas dalam tubuhnya sebagai upaya menghasilkan energi yang diperlukan untuk kehidupannya, seperti beraktifitas dan penyesuaian terhadap lingkungan.. Panas yang diproduksi tergantung dari aktifitas ternak dan intake pakan, feed intake dinyatakan dalam TDN yang menunjukkan total bahan pakan dapat dicerna oleh ternak (Rahardja, 2007). Perolehan panas berasal dari energi pakan akan menambah beban panas bagi ternak bila suhu udara lebih tinggi dari suhu nyaman, sebaliknya kehilangan panas bila suhu udara lebih rendah dari suhu nyaman.

Cekaman panas dapat dikurangi dengan pemberian naungan dan manajemen pakan pada ternak perah. Saat akses dan ketepatan penyiapan penggunaan naungan dan manajemen pakan pada sapi perah yang baik, dapat meringankan pengaruh negatif dari beban panas tubuh ternak sapi perah (Kendall et al., 2006; Tucker et al., 2008). Hal tersebut, terdapat bukti bahwa pada musim panas, nilai akses sapi perah pada naungan menunjukkan tingkah laku berdiri yang rendah dan bernaung dengan tingkah laku berbaring yang tinggi (Schütz et al., 2010). Berdasarkan hal tersebut, maka perlu melakukan penelitian mengenai manajemen pakan dan pemberian naungan dalam kaitannya dengan respon fisiologis, konsumsi pakan, TDN, dan pertambahan bobot badan, dan tingkah laku sapi perah. Pengaturan komposisi pakan merupakan cara yang efektif untuk mengurangi hilangnya nutrisi pakan ke lingkungan (Van Der Steit et al., 2008).

Penelitian ini bertujuan mempelajari dan mengetahui pengaruh konsumsi energi ransum yang berbeda terhadap respon fisiologis sapi perah dara FH sebagai efek kalorigenik. Manfaat penelitian sebagai informasi mengenai metode pemberian pakan yang baik untuk kebutuhan hidup pokok dan proses termoregulasi sapi perah dara FH. Pemberian perlakuan energi pakan konsentrat $65-70 \%$ menunjukkan respon fisiologis yang optimum sapi perah dara FH. Kombinasi lingkungan dengan pemberian energi pakan konsentrat yang 
lebih tinggi dapat meningkatkan pembebasan panas pada sapi perah dara.

\section{MATERI DAN METODE}

Penelitian ini dilaksanakan selama tiga bulan di Laboratorium Lapang, kandang sapi perah Fakultas Peternakan Institut Pertanian Bogor. Materi penelitian menggunakan empat ekor sapi perah dara FH dengan rataan bobot badan $226 \pm 60 \mathrm{~kg}$. Pakan terdiri dari hijauan dan bahan pakan lokal untuk formulasi konsentrat. Pemberian pakan $\pm 3 \%$ bahan kering dari bobot badan sapi perah dara dengan rasio hijauan dan konsentrat adalah 60 :40\%. Peralatan yang digunakan yaitu timbangan LN $110 \mathrm{~kg}$, timbangan $5 \mathrm{~kg}$, pita ukur, termometer bola basah dan bola kering, BTU-Psychrometer, infrared thermometer, pyranometer-display, termo klinis safety, stetoskop, stopwatch.

Peubah yang diamati dalam penelitian, yaitu lingkungan mikro yang pengamatannya dilakukan pada pukul 09.00-15.00 WIB dengan interval 1 jam. Suhu lingkungan $\left({ }^{\circ} \mathrm{C}\right)$, kelembaban udara (\%), Temperature Humidity Index (THI), kecepatan angin $(\mathrm{m} / \mathrm{s})$, dan radiasi matahari (watt $/ \mathrm{m}^{2}$ ). Respon fisiologis : pengamatan pada pukul 10.00, 12.00 dan 14.00. Suhu rektal/Tr $\left({ }^{\circ} \mathrm{C}\right)$, suhu permukaan kulit/Ts $\left({ }^{\circ} \mathrm{C}\right)$, suhu tubuh/Tb $\left({ }^{\circ} \mathrm{C}\right)$, denyut jantung/Hr (kali/menit), frekuensi respirasi/Rr (kali/menit), serta konsumsi ransum (BK, TDN, PK) dan PBB sapi perah dara.

$\begin{array}{ccc}\text { Rancangan } & \text { penelitian } & \text { yang } \\ \text { digunakan adalah } & \text { Rancangan } & \text { Bujur }\end{array}$

Sangkar Latin dengan pola 4 x 4 , perlakuan yang diujikan yaitu P1 (pakan konsentrat dengan TDN 60\%), P2 (pakan konsentrat dengan TDN 65\%), P3 (pakan konsentrat dengan TDN 70\%), dan P4 (pakan konsentrat dengan TDN 75\%). Setiap periode berlangsung selama 21 hari dengan masa adaptasi 14 hari pertama dari 18 hari pengamatan respon fisiologis. Data mengenai iklim mikro dianalisis secara statistik untuk mendapatkan rataan dan standar deviasi. Respon fisiologis dianalisis menggunakan sidik ragam (Anova). Untuk menguji perbedaan nilai rata-rata pada peubah yang diukur dari setiap perlakuan pakan konsentrat diketahui melalui uji Beda Nyata Terkecil (Steel dan Torrie, 1995).

\section{HASIL DAN PEMBAHASAN}

\section{Kondisi Lingkungan Mikro}

Hasil pengamatan selama penelitian yang berlangsung mulai pukul 09.00 pagi sampai pukul 15.00 sore WIB, data yang diperoleh menunjukkan bahwa suhu lingkungan berkisar antara $27,4-33,2^{\circ} \mathrm{C}$, kelembaban udara antara 59.1-89.7\%, THI (Temperature Humidity Index) antara 77,182,7, kecepatan angin 0,35-1,10 meter/detik dan energi radiasi matahari berkisar antara 210,8-459,9 watt $/ \mathrm{m}^{2}$. Nilai hasil pengamatan yang diperoleh lebih tinggi dibandingkan rataan kisaran nilai optimum untuk tingkat kenyamanan sapi perah. Kisaran zona termonetral sapi perah berada pada suhu udara antara $13-25^{\circ} \mathrm{C}$ dan kelembaban udara antara 50-60\% (McNeilly,2001). 
Panas lingkungan tergantung dari suhu dan kelembaban udara, kecepatan angin, radiasi matahari, kepadatan kandang, dan pelepasan panas metabolis tubuh ternak (Berman, 2008). Oleh karena itu, dapat diduga bahwa sapi perah dara $\mathrm{FH}$ hasil pengamatan mengalami cekaman panas pada kondisi lingkungan tersebut. Berdasarkan klasifikasi Pennington dan VanDevender (2004), nilai THI tersebut menunjukan terjadinya cekaman panas sedang pada ternak. Cekaman panas sedang ditandai dengan terjadinya pelepasan panas tubuh sebanyak $50 \%$ melalui proses respirasi (Berman, 2005).

\section{Konsumsi Ransum dan Pertambahan Bobot Badan (PBB)}

Rataan tingkat konsumsi bahan kering pakan konsentrat dan pola perubahan pertambahan bobot badan sapi perah dara (Tabel 1). Konsumsi BK pakan konsentrat sapi penelitian berkisar antara 7.0-7.4 kg. Besarnya konsumsi tersebut, masih sesuai dengan anjuran NRC (2001) bahwa sapi-sapi dara FH dengan bobot badan antara $150 \mathrm{~kg}$ dan $300 \mathrm{~kg}$ dengan PBB 0,6 kg per hari dibutuhkan $\mathrm{BK}$ berkisar $4,96 \mathrm{~kg}$ dan $7,4 \mathrm{~kg}$ BK per hari. Kondisi cekaman panas, efesiensi penggunaan energi akan berkurang karena meningkatnya energi untuk hidup pokok dan energi untuk aktivitas termoregulasi. Kamanga-Sollo et al. (2011) menyatakan pada saat tubuh ternak mengalami cekaman panas, tubuh akan menurunkan laju metabolisme dengan menekan sekresi hormon tiroksin serta mengeluarkan heat shock proteins yang memiliki peranan penting untuk merespon stress panas dan jenis stress seluler lainnya dan dalam tingkat regulasi dan efisiensi perkembangan otot.

Tabel 1. Rataan konsumsi BK, TDN, PK ransum dan PBB sapi perah dara selama penelitian

\begin{tabular}{lcccc}
\hline \multirow{2}{*}{\multicolumn{1}{c}{ Peubah }} & \multicolumn{4}{c}{ Perlakuan } \\
\cline { 2 - 5 } & P1 & P2 & P3 & P4 \\
\hline Bahan Kering (kg) & $7,40 \pm 2,10$ & $7,30 \pm 1,80$ & $7,30 \pm 0,80$ & $7,30 \pm 1,20$ \\
TDN (kg) & $3,70 \pm 1,20$ & $3,80 \pm 1,00$ & $3,70 \pm 0,60$ & $3,70 \pm 0,80$ \\
Protein Kasar (kg) & $0,71 \pm 0,10$ & $0,70 \pm 0,60$ & $0,75 \pm 0,10$ & $0,75 \pm 0,10$ \\
PBB (kg) & $0,65 \pm 0,08^{\mathrm{a}}$ & $0,65 \pm 0,05^{\mathrm{a}}$ & $0,68 \pm 0,06^{\mathrm{a}}$ & $0,60 \pm 0,08^{\mathrm{b}}$ \\
\hline
\end{tabular}

Superskrip berbeda pada baris yang sama menunjukkan perbedaan yang nyata antar perlakuan $(\mathrm{P}<0,05)$.

Hasil analisis menunjukkan bahwa pertambahan bobot badan tidak perbedaan yang nyata antar perlakuan energi pakan konsentrat $\mathrm{P} 1, \mathrm{P} 2$, dan $\mathrm{P} 3 \quad(\mathrm{P}<0,05)$. Meskipun demikian, rataan $\mathrm{PBB}$ dari perlakuan P4 dengan TDN konsentrat $75 \%$ berbeda nyata dengan P1, P2, dan P3, serta jauh lebih rendah dibanding dari perlakuan lainnya yaitu sebesar $0,60 \mathrm{~kg}$ per hari.

\section{Suhu Rektal (Tr)}

Hasil pengukuran pengaruh perlakuan terhadap suhu rektal berkisar 
antara $38,6-39,2^{\circ} \mathrm{C}$ (Tabel 2). Rataan suhu rektal tersebut, masih tergolong pada suhu normal sapi perah, seperti yang dikemukakan Kelly (1984) sebesar 38,2$39,1^{\circ} \mathrm{C}$. Hasil penelitian Purwanto et al. (1995) serta Kibler (1984) melaporkan bahwa pada suhu lingkungan $30{ }^{\circ} \mathrm{C}$ serta
$32,2{ }^{\circ} \mathrm{C}$, suhu rektal dapat mencapai lebih dari $39,8^{\circ} \mathrm{C}$ serta $40{ }^{\circ} \mathrm{C}$. Kondisi suhu yang tinggi tersebut, mengindikasikan fungsi tubuh bekerja secara ekstra untuk mencapai keseimbangan panas yang baik untuk pengeluaran panas.

Tabel 2. Rataan respon fisiologis pada perlakuan energi pakan konsentrat yang berbeda

\begin{tabular}{ccccc}
\hline Waktu & \multicolumn{4}{c}{ Perlakuan } \\
\cline { 2 - 5 } Pengamatan & P1 & P2 & P3 & P4 \\
\hline Tr (rektal ${ }^{\circ}$ ) & & & \\
Pukul 10.00 & $38,6 \pm 0,11^{\mathrm{a}}$ & $38,6 \pm 0,09^{\mathrm{a}}$ & $38,8 \pm 0,15^{\mathrm{b}}$ & $39,0 \pm 0,17^{\mathrm{c}}$ \\
Pukul 12.00 & $38,8 \pm 0,07^{\mathrm{a}}$ & $38,8 \pm 0,87^{\mathrm{ab}}$ & $39,0 \pm 0,16^{\mathrm{b}}$ & $39,2 \pm 0,09^{\mathrm{c}}$ \\
Pukul 14.00 & $38,7 \pm 0,13^{\mathrm{a}}$ & $38,7 \pm 0,05^{\mathrm{ab}}$ & $38,9 \pm 0,16^{\mathrm{b}}$ & $39,2 \pm 0,10^{\mathrm{c}}$ \\
\hline Ts (kulit $\left.^{\mathrm{o}} \mathrm{C}\right)$ & & & \\
Pukul 10.00 & $36,6 \pm 0,51^{\mathrm{a}}$ & $36,7 \pm 0,62^{\mathrm{a}}$ & $37,4 \pm 0,45^{\mathrm{b}}$ & $37,6 \pm 0,30^{\mathrm{b}}$ \\
Pukul 12.00 & $36,9 \pm 0,44^{\mathrm{a}}$ & $36,9 \pm 0,60^{\mathrm{a}}$ & $37,6 \pm 0,41^{\mathrm{b}}$ & $37,9 \pm 0,23^{\mathrm{b}}$ \\
Pukul 14.00 & $36,7 \pm 0,52^{\mathrm{a}}$ & $36,8 \pm 0,51^{\mathrm{a}}$ & $37,5 \pm 0,39^{\mathrm{b}}$ & $37,8 \pm 0,19^{\mathrm{b}}$ \\
\hline Tb (tubuh $\left.{ }^{\circ} \mathrm{C}\right)$ & & & \\
Pukul 10.00 & $38,3 \pm 0,16^{\mathrm{a}}$ & $38,4 \pm 0,15^{\mathrm{a}}$ & $38,6 \pm 0,18^{\mathrm{b}}$ & $38,8 \pm 0,17^{\mathrm{c}}$ \\
Pukul 12.00 & $38,5 \pm 0,09^{\mathrm{a}}$ & $38,6 \pm 0,15^{\mathrm{a}}$ & $38,8 \pm 0,18^{\mathrm{b}}$ & $39,0 \pm 0,09^{\mathrm{c}}$ \\
Pukul 14.00 & $38,4 \pm 0,17^{\mathrm{a}}$ & $38,5 \pm 0,11^{\mathrm{a}}$ & $38,7 \pm 0,15^{\mathrm{b}}$ & $38,9 \pm 0,09^{\mathrm{c}}$ \\
\hline Hr (kali/menit) & & & & \\
Pukul 10.00 & $61,9 \pm 6,40^{\mathrm{a}}$ & $64,4 \pm 3,17^{\mathrm{a}}$ & $68,5 \pm 4,37^{\mathrm{b}}$ & $71,9 \pm 4,47^{\mathrm{b}}$ \\
Pukul 12.00 & $64,3 \pm 2,04^{\mathrm{a}}$ & $66,4 \pm 3,49^{\mathrm{a}}$ & $72,5 \pm 5,04^{\mathrm{b}}$ & $74,1 \pm 5,76^{\mathrm{b}}$ \\
Pukul 14.00 & $62,3 \pm 2,02^{\mathrm{a}}$ & $64,4 \pm 4,62^{\mathrm{a}}$ & $69,6 \pm 3,66^{\mathrm{b}}$ & $70,9 \pm 5,97^{\mathrm{b}}$ \\
\hline Rr (kali/menit) & & & \\
Pukul 10.00 & $54,8 \pm 2,16^{\mathrm{a}}$ & $56,3 \pm 2,34^{\mathrm{a}}$ & $62,4 \pm 3,12^{\mathrm{b}}$ & $64,1 \pm 2,20^{\mathrm{b}}$ \\
Pukul 12.00 & $57,4 \pm 1,82^{\mathrm{a}}$ & $59,0 \pm 2,45^{\mathrm{b}}$ & $65,1 \pm 2,40^{\mathrm{c}}$ & $66,1 \pm 2,45^{\mathrm{c}}$ \\
Pukul 14.00 & $55,6 \pm 2,31^{\mathrm{a}}$ & $56,9 \pm 0,73^{\mathrm{a}}$ & $62,9 \pm 2,76^{\mathrm{b}}$ & $63,2 \pm 2,43^{\mathrm{b}}$ \\
\hline
\end{tabular}

Huruf kecil berbeda pada baris yang sama menunjukkan perbedaan yang nyata antar perlakuan $(\mathrm{P}<0,05)$.

Hasil analisis pada Tabel 2 menunjukkan bahwa terdapat perbedaan yang nyata $(\mathrm{P}<0,05)$ antar perlakuan energi pakan konsentrat dalam pengaruhnya terhadap suhu rektal. Perlakuan P1 berbeda nyata dengan perlakuan P4 dalam pengaruhnya terhadap suhu rektal sapi perah dara FH. Konsumsi Energi TDN yang tinggi, produksi panas yang diperoleh ternak tinggi pula diakibatkan energi yang berasal dari ransum merupakan tambahan beban panas, selain dari lingkungan mikro. Fungsi tubuh bekerja secara ekstra sebagai termoregulasi untuk menyeimbangkan produksi panas dan pengeluaran panas melalui konsumsi air minum, evaporasi serta aktivitas dalam hal tingkah laku ternak. 


\section{Suhu Permukaan Kulit (Ts) dan Suhu Tubuh (Tb)}

Rataan suhu permukaan kulit sapisapi selama perlakuan bervariasi antara $36.66^{\circ} \mathrm{C}$ sampai $37.95^{\circ} \mathrm{C}$ yang terlihat pada Tabel 2. Nilai tersebut lebih besar dibandingkan dengan suhu permukaan kulit sapi yang dipelihara dalam lingkungan mikro yang nyaman yaitu berkisar $33,5{ }^{\circ} \mathrm{C}-37,1^{\circ} \mathrm{C}$ (Purwanto et al., 1995). Keadaan tersebut menunjukkan bahwa sapi-sapi yang diberi perlakuan, sebagian besar mengalami cekaman panas.

Hasil penelitian menunjukkan bahwa suhu kulit yang berbeda antar perlakuan energi pakan konsentrat $(\mathrm{P}<0,05)$ per waktu pengamatan. Perlakuan P1, P2 berbeda dengan perlakuan P3 dan P4 dalam pengaruhnya terhadap suhu permukaan kulit ternak sapi dara FH. Perlakuan P1 dan P2 memberikan pengaruh yang sama (suhu permukaan kulit $<37^{\circ} \mathrm{C}$ ), begitu juga perlakuan P3 dan P4 memberikan pengaruh yang sama pula ( suhu permukaan kulit $>37^{\circ} \mathrm{C}$ ).

Rataan suhu tubuh ternak sapi selama perlakuan energi pakan konsentrat berkisar antara $38,34^{\circ} \mathrm{C}$ sampai $39,06{ }^{\circ} \mathrm{C}$ (Tabel 2). Nilai kisaran tersebut masih tergolong yang normal $38,32-38,63^{\circ} \mathrm{C}$ pada suhu lingkungan yang nyaman (Kelly, 1984). Selain itu ada nilai suhu tubuh $39,0^{\circ} \mathrm{C}$ yang diperoleh pada waktu pengamatan pukul 12.00 dengan perlakuan P4 energi TDN tinggi 75\%. Nilai tersebut mengindikasikan sapi perah dara $\mathrm{FH}$ mengalami cekaman panas. Perbedaan konsumsi energi pada sapi menyebabkan peningkatan produksi panas (Brossh dan
Aharoni, 2001). Perubahan konsumsi energi mempengaruhi termogenesis dan nilai metabolisme basal (Demo et al., 2001). Kadar energi yang lebih tinggi menyebabkan produksi panas metabolis lebih tinggi dan selanjutnya dapat memicu peningkatan suhu tubuh.

\section{Denyut Jantung (Hr)}

Hasil analisis sidik ragam menunjukkan terdapat perbedaan yang nyata $(\mathrm{P}<0.05)$ antar perlakuan setiap waktu pengamatan. Ada kecendrungan sapi-sapi yang memperoleh perlakuan energi pakan konsentrat yang tinggi, menunjukkan denyut jantung yang tinggi pula. Hal ini berhubungan dengan aktivitas metabolisme sapi. Sapi yang memperoleh produksi panas yang tinggi mengakibatkan aktivitas metabolisme yang cepat daripada sapi yang memperoleh produksi panas yang lebih rendah. Isnaeni (2006) mengemukakan bahwa produksi panas yang tinggi cenderung meningkatkan denyut jantung, yang merupakan mekanisme untuk menjaga tekanan darah stabil akibat dilatasi pembuluh darah. Saat ada cekaman suhu udara $\left(32^{\circ} \mathrm{C}\right)$, denyut jantung mencapai 79 kali/menit (Schutz et al., 2009). Ternak mengkonsumsi konsentrat dengan tingkat energi (TDN) yang lebih tinggi, memiliki denyut jantung yang cenderung lebih tinggi terutama saat ada cekaman panas.

\section{Frekuensi Respirasi (Rr)}

Frekuensi respirasi yang tertera pada Tabel 2 umumnya tinggi, namun demikian tergolong kisaran normal sapi 
perah sesuai laporan Kibler (1984) yaitu 27-56 kali per menit dengan suhu lingkungan $2^{\circ} \mathrm{C}$ dan $26.7^{\circ} \mathrm{C}$. Yani dan Purwanto (2006), respon respirasi akibat pengaruh radiasi matahari di Bogor dengan sapi berada pada naungan mencapai frekuensi respirasi 68 kali per menit. Hasil analisis sidik ragam menunjukkan perbedaan yang nyata antar perlakuan dalam pengaruhnya terhadap laju respirasi $(\mathrm{P}<0,05)$. Pengamatan pada pukul 12.00 WIB, menunjukkan frekuensi respirasi yang tinggi diakibatkan suhu lingkungan yang panas pada siang hari, serta nyata bila memperoleh giliran perlakuan energi pakan konsentrat yang tinggi. Hasil uji lanjut memperlihatkan bahwa pengamatan pukul 12.00 menunjukkan klasifikasi perlakuan dengan energi TDN rendah (P1 dan P2), energi TDN medium (perlakuan P3), dan energi TDN tinggi (perlakuan P4).
Peningkatan frekuensi respirasi terjadi setelah ternak mulai mengkonsumsi pakan hingga empat jam berikutnya, saat itu tekanan darah memiliki kekuatan/irama yang sama dengan respirasi (Yang dan Kuo, 2000). Peningkatan frekuensi respirasi seiring dengan peningkatan suhu udara, kelembaban udara, dan nilai THI. Panas cuaca lingkungan dapat meningkatkan rataan frekuensi respirasi (Schutz et al., 2010). Peningkatan frekuensi respirasi dapat terjadi pada ternak untuk menjaga keseimbangan panas tubuh saat mengalami cekaman panas tubuh dari hasil metabolisme pakan dan cuaca lingkungan. Hal tersebut menunjukkan peningkatan laju respirasi merupakan salah satu aktivitas yang dapat dilakukan ternak agar suhu tubuhnya tidak terus menerus naik (McNeilly, 2001).

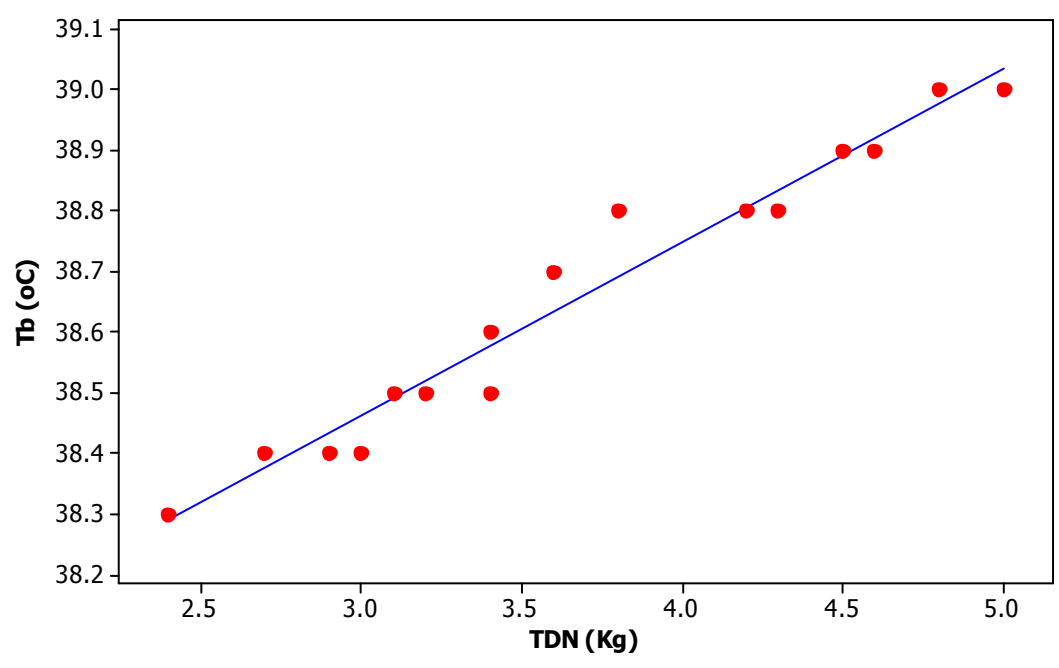

Gambar 1. Analisis Regresi TDN vs Tb

\section{Hubungan Konsumsi Energi dengan Respon Fisiologis}

Konsumsi energi pakan konsentrat pada penelitian ini menyebabkan respon fisiologis, seperti $\mathrm{Tr}$, $\mathrm{Ts}, \mathrm{Tb}, \mathrm{Hr}, \mathrm{Rr}$ mengalami peningkatan dari perlakuan $\mathrm{P} 1$ ke perlakuan P4. Terdapatnya hubungan antara konsumsi energi pakan konsentrat dengan suhu tubuh $(\mathrm{Tb})$ sapi perah dara 
FH. Persamaan regresi linier antara TDN intake dengan suhu tubuh yang ditunjukkan pada Gambar 1, yaitu persamaan $\mathrm{Tb}$ : 37,8+0,285 TDN dengan koefisien determinasi (r) 0,948, yang berarti $94,8 \%$ dapat dijelaskan dari model ini. TDN intake berpengaruh nyata terhadap $\mathrm{Tb}$ dengan peluang 0,0001, artinya bahwa peningkatan konsumsi TDN $1 \mathrm{~kg}$ akan meningkatkan $\mathrm{Tb}$ sebesar $0,285^{\circ} \mathrm{C}$.

\section{KESIMPULAN}

Sapi dara FH mencapai PBB yang optimal pada perlakuan TDN konsentrat 70\%. Peningkatan konsumsi energi TDN konsentrat dapat meningkatkan respon fisiologis. Respon fisiologis meningkat pada siang hari, mencapai puncak pada pukul 12.00-14.00 dan menurun menjelang sore hari. Model regresi antara $\mathrm{Tb}$ dan $\mathrm{Rr}$ menggambarkan proses termoregulasi yang baik, sehingga terdapat keseimbangan antara produksi panas dan pengeluaran panas. Setiap peningkatan $0,2^{\circ} \mathrm{C} \mathrm{Tb}$ maka $\mathrm{Rr}$ berubah $17,5 \mathrm{kali} / \mathrm{menit}$.

\section{DAFTAR PUSTAKA}

Berman, A. 2005. Estimates of heat stress relief needs for Holstein dairy cows. J Anim Sci 83: 1377-1384.

Berman, A. 2008. Increasing heat stress relief produced by coupled coat wetting and forced ventilation. $\mathbf{J}$ Dairy Sci 91: 4571-4578.

Brosh, A. and Y. Aharoni. 2001. Effects of feeding regimen on the diurnal pattern of heat production by dairy cows in hot climate, and on their feed intake and milk yield. Proceedings of the Symposium on energy Metabolism in Animal; Snekkersten, 11-16 Sep 2000. Wageningan Press. pp 97-100.

Demo, M., M. Klein, B. Lohrke, W. Jentsch. 2001. Effect of energy source on energy metabolism of broilers. Dalam; Energy metabolism in animals. Proceedings of the symposium on energy metabolism in animals; Snekkersten, 11-16 sep 2000. Wageningen Press. pp 129132.

Isnaeni, W. 2006. Fisiologi Hewan. Penerbit kanisius, Yogyakarta.

Kamanga-Sollo, E., A. Berman, M.S. Allen, J.P. Wang. 2011. Effects of heat stress on proliferation, protein turnover, and abundance of heat shock protein messenger ribonucleic acid in cultured porcine muscle satellite cells. J Anim Sci 89: 34733480 .

Kelly,W.R. 1984. Veterinary clinical diagnosis. Bailliere Tindall, London.

Kendall, P.E., P.P. Nielsen, J.R.Webster, G.A.Verkerk, R.P.Littlejohn, L.R. Matthews, 2006. The effects of providing shade to lactating dairy cows in a temperate climate. Livest. Sci. 103, 148-157.

Kibler, H.H. 1984. Energy metabolism and related termoregulatory reactions to thermal stress in $10^{\circ} \mathrm{C}$ and $27{ }^{\circ} \mathrm{C}$ acclimated heifers. Res. Bull. 739. 
Univ. Of Missouri, Columbia. P132.

McNeilly, A.S. 2001. Reproduction, fertility, and development. CSIRO Publishing 13:583-590.

[NRC]. National Research Council. 2001.

Nutrient Requirements of Dairy Cattle $7^{\text {th }}$ revised edition. National Academy Press.

Pennington, J.A. and K. VanDevender. 2004. Heat Stress in Dairy Cattle. http://www.uaex.edu/otherareas/publ ication/html [19 Mei 2004]

Purwanto, B.P. T. Matsumoto, F. Nakamasu, T. Ito, and S. Yamamoto, S. 1995. Effect of standing and lying behaviours on heat production of dairy heifers differing in feed intake levels. AJAS 6:271-274.

Rahardja, D.P. 2006. Ilmu Lingkungan Ternak. Citra Emulsi, Makassar.

Schütz, K.E., N.R., Cox, and L.R, Matthews. 2008. How important is shade to dairy cattle? Choice between shade or lying following different levels of lying deprivation. Applied Animal Behaviour Science 114 : 307-318.

Schutz, K.E, A.R. Rogers, N.R. Cox, C.B. Tucker. 2009. Dairy cows prefer shade that offers greater protection against solar radiation in summer: shade use, behavior, and body temperature. Appl Anim Behav Sci 116:28-34

Schutz, K.E, A.R. Rogers, N.R. Cox, C.B. Tucker. 2010. The amount of shade influences the behaviour and physiology of dairy cattle. J Dairy Sci 93:125-133.

Steel, R.G.D dan J.H. Torrie. 1995. Prinsip dan prosedur statistika. Suatu pendekatan biometrik. Terjemahan. Gramedia, Jakarta.

Tucker, C.B., A.R. Rogers, and K.E., Schütz. 2008. Effect of solar radiation on dairy cattle behaviour, use of shade and body temperature in a pasture-based system. Applied Animal Behaviour. Science 109:141-154.

Tyler, H.D, and M.E, Ensminger. 2006. Dairy cattle science. $4^{\text {th }}$ edition. Pearson education, Inc., Upper Saddle River, New Jersey.

Van Der Steit B, J.B. Wheclock, J.P. Wang. 2008. Effects of dietary protein and energy levels on cow manure exeretion and ammonia volatilization. J Dairy Sci 91:48114821.

Yani, A., dan B.P. Purwanto. 2006. Pengaruh Iklim Mikro terhadap Respons Fisiologis Sapi Peranakan Fries Holland dan Modifikasi Lingkungan untuk Meningkatkan Produktivitasnya (ulasan). Media Peternakan 29:35-46.

Yang, C.C. and T..B Kuo. 2000. Impact of pulse pressure on the respiratoryrelated arterial presure variability and its autonomic control in the rat. Pflugers Arch. 439:772-780. 